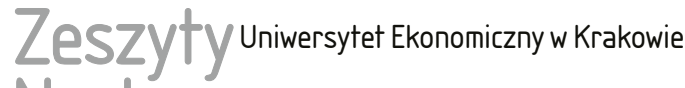 rister
}

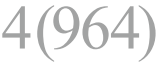

ISSN 1898-6447

Zesz. Nauk. UEK, 2017: 4(964): 27-47 DOI: 10.15678/ZNUEK.2017.0964.0402

Anna Jawor-Joniewicz

Barbara Sajkiewicz

\section{Motywowanie różnorodnego zespołu pracowniczego}

\section{Streszczenie}

Badania dowodzą istnienia wpływu zaangażowania pracowników na innowacyjność i osiągane przez nich wyniki. W procesie kształtowania tak pożądanej przez pracodawców postawy (przez dobór skutecznych instrumentów motywowania) niezbędne wydaje się zastosowanie podejścia możliwie najbardziej zindywidualizowanego, co pozwoli na pełniejsze zaspokojenie potrzeb osób zatrudnionych. Celem artykułu jest analiza metod i narzędzi motywowania różnorodnych grup pracowników, z uwzględnieniem ich płci, wieku, wykształcenia, formy zatrudnienia, stażu pracy oraz stanowiska. Poszukiwano odpowiedzi na pytanie, czy osoby podobne pod względem wymienionych cech są wrażliwe na podobne instrumenty motywowania. Wykorzystano w tym celu wyniki badań jakościowych i ilościowych zrealizowanych przez Instytut Pracy i Spraw Socjalnych w 104 przedsiębiorstwach średnich i dużych.

Słowa kluczowe: zarządzanie różnorodnością, zarządzanie zasobami ludzkimi, zaangażowanie, systemy motywacyjne.

Klasyfikacja JEL: M5.

Anna Jawor-Joniewicz, Instytut Pracy i Spraw Socjalnych, Zakład Zarządzania Zasobami Ludzkimi, ul. J. Bellottiego 3b, 01-022 Warszawa, e-mail: a.jawor@ipiss.com.pl

Barbara Sajkiewicz, Instytut Pracy i Spraw Socjalnych, Zakład Zarządzania Zasobami Ludzkimi, ul. J. Bellottiego 3b, 01-022 Warszawa, e-mail: b.sajkiewicz@ipiss.com.pl 


\section{Wprowadzenie}

W ciągu ostatnich kilku lat polski rynek pracy podlegał stałym zmianom. Część z nich wpisuje się w trendy obserwowane w większości krajów Unii Europejskiej. Pracodawcy borykają się z problemem luk kompetencyjnych, coraz trudniej jest im pozyskać do pracy osoby o szczególnie poszukiwanej wiedzy i umiejętnościach (por. [UKCES Employer... 2015, Kocór i Strzebińska 2010, Worek i in. 2011]). Jednocześnie w związku z procesem starzenia się społeczeństw firmy zmuszone są do silnego konkurowania o najmłodszych kandydatów do pracy, dbania o wydłużenie aktywności zawodowej specjalistów z największym doświadczeniem oraz wdrażania programów zarządzania wiekiem. Systematycznie w przedsiębiorstwach funkcjonujących w Polsce wrasta także liczba cudzoziemców. Ponadto nieustannie ma miejsce optymalizacja kosztów, w tym kosztów pracy. Zjawiska te wymagają od pracodawców tworzenia nowych oraz modyfikacji dotychczasowych rozwiązań z zakresu zarządzania zasobami ludzkimi, uwzględniających rosnące zróżnicowanie zespołów pracowniczych ${ }^{1}$. Zagadnienie to jest tematem niniejszego artykułu. Jego celem jest przedstawienie metod i narzędzi motywowania wykorzystujących różnice w preferencjach i oczekiwaniach różnorodnych (pod względem płci, wieku, wykształcenia, formy zatrudnienia, stażu pracy oraz piastowanego stanowiska) grup pracowników. Przedstawiono zindywidualizowane podejście do motywowania, zgodnie z prezentowaną w literaturze przedmiotu oraz stosowaną w praktyce definicją, uznającą, że „motywowanie to kształtowanie motywacji pracowników”, a więc „,siły motorycznej ich zachowań i działań jako wypadkowej różnych wpływów" [Borkowska 2006, s. 333 i 687]. Jednym z takich pozytywnych zachowań, na które autorki chcą zwrócić uwagę, jest przyjmowanie przez pracowników postawy wysokiego zaangażowania.

\section{Motywowanie do zaangażowania}

W dobie wzrastającej konkurencji o pozyskanie i utrzymanie w firmie specjalistów czy pracowników młodych szczególnego znaczenia nabiera opracowanie i wdrożenie systemów motywowania ukierunkowanych na budowanie zaangażowania, możliwie najlepiej dopasowanych do potrzeb i oczekiwań poszczególnych

1 W opracowaniu terminy ,zespół”, ,grupa” i „kategoria” pracowników stosowane są zamiennie, zgodnie z ich definicjami sformułowanymi w Słowniku Języka Polskiego (,zespół” - grupa ludzi wspólnie pracujących lub robiących coś w jakiejś dziedzinie, „grupa” - zbiorowość, której członkowie połączeni są jakąś więzią, zespół ludzi, „kategoria” - grupa ludzi, przedmiotów, zjawisk itp. wyróżniona ze względu na jaką́s cechę wspólną. Zob. www.sjp.pwn.pl (data dostępu: 6.07.2017). 
grup zatrudnionych. Postawa zaangażowania oraz towarzysząca jej zwykle satysfakcja z pracy w danej organizacji może uchronić pracodawcę przed wzrostem fluktuacji pracowników oraz odpływem osób o najcenniejszych kompetencjach. Zaangażowanie osób zatrudnionych sprzyja zarazem poprawie efektów ich pracy oraz zwiększeniu innowacyjności (por. [Rola ZZL... 2010, Lawler, Mohrman i Benson 2001], co wzmacnia pozycję konkurencyjną firm.

Należy zatem postawić pytanie, czym jest zaangażowanie i jak można je kształtować. Sam termin jest wieloznaczny, bywa ujmowany jako: 1) oddanie dla realizacji powierzonych pracownikowi zadań i identyfikowanie się z nimi, 2) współuczestnictwo, zaangażowanie w firmę, związane $\mathrm{z}$ identyfikowaniem się z jej wartościami i celami (commitment), 3) zaangażowanie w wykonywany zawód oraz 4) identyfikacja ze środowiskiem społecznym organizacji [Rola ZZL... 2010, s. 45]. Dla przedsiębiorców szczególnie istotne będzie zaangażowanie typu 1 i 2. Analizy wyników badań zagranicznych oraz krajowych, w tym Instytutu Pracy i Spraw Socjalnych (IPiSS), wskazują na istnienie rozwiązań, dzięki którym organizacje mogą świadomie kształtować zaangażowanie pracowników. W procesie budowania tej cennej postawy pracowniczej kluczowego znaczenia nabiera odpowiedni dobór praktyk oraz instrumentów zarządzania zasobami ludzkimi.

$\mathrm{Z}$ analiz literatury przedmiotu wynika, że korzystny wpływ na budowanie zaangażowania wywierają takie praktyki, jak (por. [Kochan i Dyer 1993, Smith 2006, Croston 2008, Cook 2008, Federman 2009, Halm 2011, Kaye i Jordan-Evans 2012, Bridger 2015]):

- upełnomocnienie (empowerment) pracowników,

- wspieranie przywództwa,

- doskonalenie komunikacji w organizacji,

- poszerzanie elastyczności,

- wyznaczanie ambitnych zadań, udział w atrakcyjnych projektach,

- zapewnienie pracownikom stałego rozwoju,

- budowanie kultury organizacyjnej wzmacniającej zaangażowanie.

Część badaczy, twórców koncepcji wysoce efektywnych systemów pracy (zwłaszcza opartych na zaangażowaniu high involvement work practices i high commitment work systems), zwraca uwagę na szczególną skuteczność stosowania określonych wiązek praktyk. J.P. Guthie [2001] kładzie nacisk na m.in.: wynagradzanie oparte na kompetencjach, stosowanie premii grupowych, zespołową organizację pracy, rozwój partycypacji, zachęcanie do dzielenia się wiedzą oraz regularne prowadzenie badań postaw pracowniczych. Natomiast E.E. Lawler III zwraca uwagę na przydatność: szerokiego włączania wszystkich zatrudnionych w procesy decyzyjne, udrożnienia kanałów komunikacyjnych i stworzenia dostępu do zasobów informacji o firmie oraz zasadach jej funkcjonowania, 
dzielenia się wiedzą, a także uzależnienia wynagrodzeń od efektów pracy (por. [Konrad 2006, s. 2]).

Wagę stosowania wysoce efektywnych systemów pracy opartych na zaangażowaniu potwierdziły także polskie badania. Zgodnie z wynikami analiz Instytutu Pracy i Spraw Socjalnych największy wpływ na budowanie tej postawy wywierają: 1) docenianie przez przełożonych wysiłków i osiągnięć pracowników, 2) poszerzenie możliwości rozwoju, 3) wyznaczanie ambitnych celów, 4) usprawnienie przepływu informacji, 5) zwiększenie partycypacji decyzyjnej, 6) wsparcie ze strony bezpośredniego przełożonego oraz 7) uświadomienie pracownikowi związku jego zadań z celami firmy [Rola ZZL... 2010, s. 93]. Badania M. Juchnowicz [2012, s. 94] wskazywały natomiast duże znaczenie stosowania w procesie kształtowania zaangażowania: wynagradzania za efekty, tworzenia możliwości rozwoju, zapewnienia dobrych relacji ze współpracownikami, partycypacji (decyzyjnej i finansowej) oraz samodzielności wyboru sposobu wykonania zadań.

Specjaliści z zakresu zarządzania zasobami ludzkimi dysponują rozwiązaniami, dzięki którym mogą skutecznie wspierać zwiększenie motywacji do pracy osób zatrudnionych. O tym, jak pilna jest to potrzeba, świadczą wyniki badań zarówno światowych, jak i krajowych, wskazujące, że zaledwie 30\% załogi przedsiębiorstw to osoby mocno zaangażowane w pracę [Rashid, Sambasivan i Johari 2003, s. 702; Colan 2009, s. 3; Juchnowicz 2012, s. 84]. Może to świadczyć o niedoskonałości funkcjonujących w przedsiębiorstwach systemów motywowania, nieuwzględniających pełni potrzeb i oczekiwań pracowników [Rodgers i Hunter 2003, s. 223], które - jak wynika z badań - bywają różne w zależności od cech społeczno-demograficznych osób zatrudnionych. Analizy B. Kaye i S. Jordan-Evans [2012] koncentrują się na znaczeniu kierowania się przy doborze stosowanych metod i narzędzi budowania zaangażowania wiekiem zatrudnionych i związanymi z nim specyficznymi potrzebami. Polska badaczka, A. Wziątek-Staśko [2012, s. 104-145], zauważa, że nie tylko wiek, ale także płeć może być istotnym czynnikiem wpływającym na oceny skuteczności wdrażanych instrumentów motywowania.

Wydaje się zatem, że w procesie budowania zaangażowania załogi doniosłym wyzwaniem staje się możliwie najlepsze dopasowanie stosowanych rozwiązań do indywidualnych potrzeb pracowników lub (z racji skali przedsiębiorstw) ich grup. Podejście takie jest zgodne z założeniami zarządzania różnorodnością ${ }^{2}(Z R)$, które cieszy się rosnącym zainteresowaniem wśród praktyków ZZL, także w Polsce.

2 Zarządzanie różnorodnością można ująć jako: „strategię zarządzania personelem opierającą się na przekonaniu, że różnorodność personelu (wszystkie możliwe aspekty, pod których względem ludzie się od siebie różnią i są do siebie podobni) jest jednym z kluczowych zasobów organizacji, który w określonych warunkach może stać się źródłem korzyści biznesowych" ([Kirton i Greene 2005], cyt. za: [Gryszko, 2009, s. 5]). 


\section{Kontekst zarządzania różnorodnością w badaniach IPiSS poświęconych zaangażowaniu}

Problematyce budowania zaangażowania pracowników w kontekście zarządzania różnorodnością poświęcone zostały badania realizowane w latach 2014-2015 przez zespół Instytutu Pracy i Spraw Socjalnych ${ }^{3}$ w ramach umowy z Narodowym Centrum Nauki (UMO-2012/07/B/HS4/03008). Ich głównym celem była analiza najbardziej skutecznych metod i narzędzi motywowania różnorodnych grup pracowników. W projekcie podjęto próbę określenia instrumentów kształtowania zaangażowania organizacyjnego pracowników najlepiej uwzględniających potrzeby i oczekiwania osób różnej płci, w różnym wieku, o różnym wykształceniu i stażu pracy, na różnych stanowiskach, zatrudnionych w różnych formach. Zainteresowania badaczy koncentrowały się ponadto na problematyce powszechności stosowania zarządzania różnorodnością oraz barierach kształtowania zaangażowania różnorodnych grup pracowników.

Badania miały charakter zarówno jakościowy, jak i ilościowy. Przebiegały w dwóch etapach. W pierwszym zrealizowano dwa zogniskowane wywiady grupowe (FGI) z udziałem pracowników firm średnich i dużych. W drugim natomiast przeprowadzono ankietę wśród 2045 pracowników różnej płci, w różnym wieku, zatrudnionych w ramach różnego typu umów, na różnych stanowiskach, mających różny staż pracy, reprezentujących 104 przedsiębiorstwa średnie i duże z branż wiedzochłonnych. Ponadto zrealizowane zostały 104 indywidualne wywiady pogłębione z osobami kierującymi działami ZZL tych firm.

W niniejszym artykule zaprezentowano najważniejsze wyniki przeprowadzonych badań, przy czym skoncentrowano się na opiniach dotyczących instrumentów motywowania wyrażonych przez pracowników firm średnich i dużych.

\section{Skala stosowania zarządzania różnorodnością}

Mimo że idea zarządzania różnorodnością nie jest nowa, a w Stanach Zjednoczonych i UE wiele przedsiębiorstw od lat z powodzeniem je stosuje, w polskiej rzeczywistości gospodarczej nadal nie jest ono zjawiskiem powszechnym. Jak wynika z badań przeprowadzonych w 2005 r. wśród organizacji reprezentujących 25 krajów członkowskich UE, 42\% firm zrzeszonych w ramach Europejskiego Panelu Testów Biznesowych (EBTP), stosowało ZR od ponad pięciu lat, a kolejne

${ }^{3}$ W skład zespołu badawczego wchodzili pracownicy Zakładu Zarządzania Zasobami Ludzkimi: prof. dr hab. S. Borkowska, dr A. Jawor-Joniewicz, dr A. Rogozińska-Pawełczyk i mgr B. Sajkiewicz. Wyniki projektu badawczego zostały omówione w pracy pt. Kształtowanie zaangażowania pracowników w kontekście zarzq̨dzania różnorodnościq [2016]. 
$27 \%$ wdrożyło je w ciągu pięciu lat poprzedzających badanie [The Business Case... 2005]. W naszym kraju tylko co piąte przedsiębiorstwo wprowadza jakiekolwiek rozwiązania z zakresu zarządzania różnorodnością, a spójną, oficjalną strategię posiada zaledwie $2 \%$ firm (por. analizy Forum Odpowiedzialnego Biznesu oraz wyniki badań Konfederacji Lewiatan Barometr Różnorodności [Gryszko 2009, s. 5; Lisowska i Sznajder 2013, s. 7-8; Lisowska i Sznajder 2014, s. 12]). Podobne wyniki uzyskano w omawianych badaniach IPiSS. Sformalizowaną strategię ZR wdrożyło 2,8\% objętych analizami organizacji średnich i dużych. Zdecydowana większość kierujących działami ZZL nie potrafiła jednoznacznie zdefiniować samego pojęcia zarządzania różnorodnością, a część przyznała się, że spotyka się $\mathrm{z}$ tym terminem po raz pierwszy. Częstym błędem było ponadto mylenie przez badanych zarządzania różnorodnością z polityką równych szans w miejscu pracy.

Jednocześnie mniej niż połowa objętych ankietyzacją pracowników firm $(46,9 \%)$ uznała, że ich pracodawcy uwzględniają w procesie zarządzania organizacją potrzeby i oczekiwania zatrudnionych.

Tworzenie systemów motywowania w oderwaniu od oczekiwań pracowników oraz niewystarczające różnicowanie instrumentów budowania ich zaangażowania może w istotny sposób obniżać skuteczność podejmowanych działań.

\section{Sposoby motywowania różnorodnego zespołu pracowników}

Analiza statystyczna ${ }^{4}$ uzyskanych przez IPiSS wyników wskazuje na istnienie zróżnicowanego oddziaływania określonych kategorii instrumentów motywowania na różne grupy pracowników. Na potrzeby tej analizy poszczególne instrumenty zostały połączone w cztery kategorie syntetyczne:

- wynagradzanie (instrumenty związane z szeroko pojętym wynagradzaniem oraz świadczeniami dodatkowymi, np. służbowy samochód, laptop, telefon, dodatkowe ubezpieczenie zdrowotne, karnety sportowo-rekreacyjne),

- satysfakcjonujące środowisko pracy (instrumenty związane z tzw. bezpieczeństwem i stabilnością zatrudnienia, ponadto zgodność wartości własnych z firmowymi, zapewnienie pracownikowi samodzielności i umożliwienie decydowania o sposobie wykonania zadań, umożliwienie zgłaszania propozycji usprawnień, delegowanie odpowiedzialności),

- relacje interpersonalne (instrumenty związane $\mathrm{z}$ atmosferą $\mathrm{w}$ pracy, komunikacją $\mathrm{w}$ firmie, łatwy dostęp do informacji, partnerskie relacje z przełożonym,

${ }^{4}$ Analiza statystyczna wyników została przeprowadzona przez dr. P. Chmielarza. Zob. rozdział pt. Wielowymiarowa analiza czynnikowa narzędzi kształtujacych zaangażowanie pracowników w pracy [Kształtowanie zaangażowania... 2016]. 
zapewnienie równowagi między pracą a życiem, równe traktowanie pracowników w miejscu pracy),

- rozwój (instrumenty związane z możliwościami rozwoju kompetencji, łatwy dostęp do programów rozwojowych, możliwość udziału w atrakcyjnym projekcie, uzyskiwanie informacji zwrotnej z ocen okresowych).

Tak pogrupowane czynniki motywacyjne zostały skonfrontowane z opiniami pracowników. Przeprowadzone analizy statystyczne ${ }^{5}$ miały m.in. na celu określenie wrażliwości różnych grup zatrudnionych na poszczególne rodzaje sposobów motywowania. Wykazały one istnienie zależności, które przedstawiono poniżej. Są one rekomendowane pracodawcom do rozważenia przy projektowaniu systemów motywowania.

Największe zainteresowanie budzą ostatnio grupy wiekowe pracowników. Firmy, które deklarują stosowanie zasad zarządzania różnorodnością, najczęściej ograniczają się do uwzględniania różnorodności pod względem wieku pracowników. Analiza statystyczna wykazuje przede wszystkim bardzo niską podatność osób najmłodszych (w analizie przyjęto, że to osoby do 35 roku życia) na wszystkie czynniki motywowania oraz podatność na nie pracowników pozostałych kategorii wiekowych (w analizie określono je jako: 36-45 lat, 46-55 lat oraz 56 i więcej lat). W grupach wiekowych 36-45 lat i 46-55 lat stwierdzono dość podobne reakcje. Cechuje je wysoka podatność na narzędzia należące do wszystkich kategorii motywatorów. Grupa najstarszych respondentów wykazuje ogólną wrażliwość na średnim poziomie, ale najbardziej ze wszystkich pracowników reaguje na czynniki związane z wynagradzaniem. Można pokusić się o uogólnienie, że pod względem wieku mamy dwie grupy pracowników o różnej wrażliwości na instrumenty motywowania: grupę młodych pracowników (niewrażliwych na motywowanie) i pozostałych (wrażliwych na motywowanie).

Podobnie przedstawiają się reakcje na środki motywowania pracowników ze względu na staż pracy. Wyraźnie wyróżnia się grupa pracowników ze stażem 1-3 lat, prezentując bardzo wysoką podatność na narzędzia związane z rozwojem, relacjami interpersonalnymi oraz satysfakcjonującym środowiskiem pracy. Jest to zwykle etap w rozwoju kariery zawodowej, kiedy pracownik stabilizuje swoją pozycję w organizacji i ocenia, co może w niej osiągnąć. Pracodawca, chcąc zatrzymać takiego pracownika w firmie, powinien zadbać bardziej o jego rozwój niż o atrakcyjną płacę. Czynniki dotyczące wynagrodzenia były szczególnie istotne dla najdłużej pracujących.

5 Wartości syntetycznych czynników zostały wykorzystane do porównania grup respondentów. Zastosowano analizę wskaźników korelacji i odpowiednio: test $t$-Studenta, analizę wariancji $\mathrm{z}$ testem Tukeya (Tukey honest significant differences), test homogeniczności wariancji Bartletta i Fligner-Killeena, test normalności rozkładu Shapiro-Wilka, test U Manna-Whitneya, porównanie wartości medianowych Kruskala-Wallis. 
Biorąc pod uwagę płeć respondentów, w przeprowadzonych analizach wykazano, że mężczyźni przejawiali statystycznie większą niż kobiety podatność na wszystkie wyodrębnione kategorie narzędzi motywowania. Jeśli chodzi o poziom wykształcenia, najbardziej podatne na wszystkie czynniki okazały się osoby z wykształceniem podstawowym. Szczególnie mocno działają na tę grupę czynniki związane ze środowiskiem pracy. Pracownicy z ukończoną szkołą średnią najsilniej reagują na bodźce związane z rozwojem. Bardzo niską podatność na motywację zewnętrzną wykazali pracownicy z wyższym wykształceniem. Nie stwierdzono w ich przypadku żadnych korelacji dodatnich z instrumentami motywowania.

W badaniach uwzględniono też podział pracowników na trzy główne typy stanowisk: menedżerów, specjalistów i pracowników wykonawczych. Wyniki badań ostatniej wymienionej grupy cechował brak istotności statystycznej. Menedżerowie i specjaliści reagują natomiast całkowicie odmiennie. Dla menedżerów charakterystyczne jest szczególnie duże zainteresowanie ofertą rozwojową firmy oraz instrumentami związanymi z relacjami interpersonalnymi, ale także pewna wrażliwość na czynniki wynagrodzeniowe (choć znacznie mniejsza niż w przypadku pozostałych czynników). Jeśli chodzi o specjalistów, stwierdzono tylko podatność na instrumenty należące do grupy wynagrodzeń, ale również ta nie jest zbyt silna.

Z pewnymi trudnościami wiąże się interpretacja zależności statystycznych przy podziale pracowników ze względu na formę zatrudnienia. Odnotowano brak korelacji w przypadku pracowników z umową o pracę w pełnym wymiarze. Dla osób zatrudnionych w niepełnym wymiarze istotne są relacje interpersonalne i środowisko pracy, a dla pracowników zatrudnionych na podstawie umów cywilnoprawnych liczy się rozwój.

Analizę odpowiedzi na pytania pozwalające szczegółowo zidentyfikować preferencje respondentów w zakresie motywowania i budowania zaangażowania zaprezentowano $\mathrm{w}$ tabeli 1 . Zestawiono w niej czynniki niepogrupowane w szersze kategorie.

Zaprezentowane w tabeli 1 zestawienie pozwala uświadomić sobie skalę rozbieżności w reakcjach różnych pracowników na stosowane przez pracodawcę instrumenty motywowania i budowania zaangażowania. Jest oczywiste, że każda firma posiada zespół pracowniczy o niepowtarzalnej strukturze. Częściowo zależy to od branży, w której funkcjonuje organizacja. W organizacjach wiedzy kluczową grupą pracowników są zwykle osoby z wyższym wykształceniem i przeważają stanowiska specjalistyczne. Nierzadko duży jest tam udział osób zatrudnionych na podstawie umów cywilnoprawnych. Zupełnie inna jest struktura zatrudnienia $\mathrm{w}$ przedsiębiorstwie przemysłowym. Większy jest odsetek pracowników z wykształceniem średnim lub zasadniczym zawodowym, pracujących na stanowiskach wykonawczych, z umową o pracę na czas nieokreślony. Ponadto w przed- 
siębiorstwie takim pracuje zwykle więcej mężczyzn. Aby osiągnąć wysoką skuteczność systemów motywowania, trzeba zróżnicować stosowane środki, uwzględniając rzeczywistą strukturę zespołu pracowniczego, konkretne postawy, potrzeby i oczekiwania. Pracodawcy chwalą sobie informacje pozyskiwane od pracowników w ramach badań satysfakcji czy badań zaangażowania, które są coraz powszechniejsze. Ich wyniki stanowią doskonałą podstawę do opracowania, a następnie korygowania systemów motywowania, tak by uwzględniały różnorodność ich adresatów.

Tabela 1. Czynniki motywowania istotne dla różnych grup zatrudnionych według opinii pracowników

\begin{tabular}{|l|l|}
\hline \multicolumn{1}{|c|}{ Pracownicy } & \multicolumn{1}{c|}{ Czynniki } \\
\hline Kobiety & $\begin{array}{l}\text { - równe traktowanie wszystkich pracowników w miejscu pracy } \\
\text { - dobra atmosfera w miejscu pracy } \\
\text { - dbanie o zapewnienie równowagi pomiędzy pracą a życiem } \\
\text { osobistym }\end{array}$ \\
\hline Mężczyźni & $\begin{array}{l}\text { - wysokość wynagrodzenia } \\
\text { - docenianie przez przełożonego i wyrażane przez niego } \\
\text { uznanie }\end{array}$ \\
\hline Osoby w wieku do 35 lat & $\begin{array}{l}\text { - możliwość stałego rozwoju } \\
\text { - możliwość decydowania o sposobie realizacji zadań } \\
\text { - czynniki związane z atrakcyjnym środowiskiem pracy }\end{array}$ \\
\hline Osoby w wieku 36-45 lat & $\begin{array}{l}\text {-swiadczenia dodatkowe (samochód, telefon, laptop) } \\
\text { - możliwość rozwoju } \\
\text { - przejrzysta ścieżka kariery zawodowej }\end{array}$ \\
\hline $\begin{array}{l}\text { Osoby w wieku 46-55 lat } \\
\text { - dobra komunikacja w firmie (w ramach działu i pomiędzy } \\
\text { różnymi działami firmy) }\end{array}$ \\
- dobra atmosfera w miejscu pracy \\
- równe traktowanie wszystkich pracowników \\
- stabilność zatrudnienia \\
- świadczenia dodatkowe \\
56 i więcej lat
\end{tabular}


cd. tabeli 1

\begin{tabular}{|c|c|}
\hline Pracownicy & Czynniki \\
\hline Menedżerowie & $\begin{array}{l}\text { - stworzenie warunków do samorealizacji } \\
\text { - zdefiniowanie obowiązków w taki sposób, by praca była } \\
\text { wyzwaniem } \\
\text { - atrakcyjne wynagrodzenie }\end{array}$ \\
\hline Pracownicy wykonawczy & $\begin{array}{l}\text { - możliwość zgłaszania propozycji usprawnień } \\
\text { - nagradzanie najlepszych pomysłów } \\
\text { - ocenianie pracy i wyrażanie uznania dla pracy przez przeło- } \\
\text { żonego }\end{array}$ \\
\hline Specjaliści & $\begin{array}{l}\text { - możliwości rozwoju kompetencji } \\
\text { - swoboda w decydowaniu o sposobach realizacji zadań } \\
\text { - wysoki prestiż firmy }\end{array}$ \\
\hline $\begin{array}{l}\text { Pracujący w firmie krócej } \\
\text { niż rok }\end{array}$ & $\begin{array}{l}\text { - dobra atmosfera w miejscu pracy } \\
\text { - dobra komunikacja w firmie } \\
\text { - równe traktowanie wszystkich pracowników w miejscu pracy }\end{array}$ \\
\hline Pracujący w firmie 1-3 lat & $\begin{array}{l}\text { - udział w atrakcyjnym szkoleniu/konferencji } \\
\text { - możliwość stałego rozwoju kompetencji i łatwy dostęp } \\
\text { do programów rozwojowych } \\
\text { - stosowanie przejrzystych kryteriów wynagradzania } \\
\text { i awansów }\end{array}$ \\
\hline Pracujący w firmie 4-10 lat & $\begin{array}{l}\text { - atrakcyjne wynagrodzenie } \\
\text { - nagrody finansowe lub rzeczowe dla najlepszych } \\
\text { pracowników } \\
\text { - możliwości stałego rozwoju kompetencji i łatwy dostęp } \\
\text { do programów rozwojowych }\end{array}$ \\
\hline $\begin{array}{l}\text { Pracujący w firmie powyżej } \\
10 \text { lat }\end{array}$ & $\begin{array}{l}\text { - atrakcyjne wynagrodzenie } \\
\text { - nagrody finansowe lub rzeczowe dla najlepszych } \\
\text { pracowników } \\
\text { - docenianie przez przełożonego i wyrażone przez niego } \\
\text { uznanie }\end{array}$ \\
\hline $\begin{array}{l}\text { Pracujący w pełnym wymiarze } \\
\text { - umowa o pracę }\end{array}$ & $\begin{array}{l}\text { - atrakcyjne wynagrodzenie } \\
\text { - karnety sportowo-rekreacyjne finansowane przez firmę } \\
\text { - premia uzależniona od efektów pracy }\end{array}$ \\
\hline $\begin{array}{l}\text { Pracujący w niepełnym } \\
\text { wymiarze - umowa o pracę }\end{array}$ & $\begin{array}{l}\text { - równe traktowanie wszystkich pracowników w miejscu pracy } \\
\text { - dobra atmosfera w miejscu pracy } \\
\text { - dobra komunikacja w firmie }\end{array}$ \\
\hline Telepracownicy & $\begin{array}{l}\text { - możliwość zgłaszania propozycji usprawnień i nagradzanie } \\
\text { najlepszych pomysłów } \\
\text { - dobra komunikacja w firmie } \\
\text { - wspieranie pracy zespołowej }\end{array}$ \\
\hline $\begin{array}{l}\text { Zatrudnieni na podstawie umów } \\
\text { cywilnoprawnych }\end{array}$ & $\begin{array}{l}\text { - dobra komunikacja w firmie } \\
\text { - równe traktowanie wszystkich pracowników w miejscu pracy } \\
\text { - dobra atmosfera w miejscu pracy }\end{array}$ \\
\hline
\end{tabular}

Źródło: opracowanie własne na podstawie [Kształtowanie zaangażowania... 2016, s. 167-168]. 
Tabela 2. Instrumenty motywowania i budowania zaangażowania według najbardziej podatnych na nie odbiorców

\begin{tabular}{|c|c|}
\hline $\begin{array}{c}\text { Instrumenty budowania } \\
\text { zaangażowania }\end{array}$ & Najbardziej podatni odbiorcy \\
\hline Atrakcyjne wynagrodzenie & $\begin{array}{l}\text { - pracujący powyżej } 4 \text { lat } \\
\text { - pracujący w pełnym wymiarze - umowa o pracę } \\
\text { - menedżerowie } \\
\text { - mężczyźni }\end{array}$ \\
\hline $\begin{array}{l}\text { Czynniki związane } \\
\text { z atrakcyjnym środowiskiem } \\
\text { pracy }\end{array}$ & osoby w wieku do 35 lat \\
\hline $\begin{array}{l}\text { Dbanie o zapewnienie } \\
\text { równowagi pomiędzy pracą } \\
\text { a życiem osobistym }\end{array}$ & kobiety \\
\hline $\begin{array}{l}\text { Decydowanie o realizacji } \\
\text { powierzonych zadań }\end{array}$ & osoby z wykształceniem podstawowym i zawodowym \\
\hline $\begin{array}{l}\text { Dobra atmosfera w miejscu } \\
\text { pracy }\end{array}$ & $\begin{array}{l}\text { - kobiety } \\
\text { - osoby w wieku } 46-55 \text { lat } \\
\text { - pracujący w firmie krócej niż rok } \\
\text { - pracujący w niepełnym wymiarze - umowa o pracę } \\
\text { - zatrudnieni na podstawie umów cywilno- } \\
\text { prawnych }\end{array}$ \\
\hline Dobra komunikacja w firmie & $\begin{array}{l}\text { - osoby w wieku } 46-55 \text { lat } \\
\text { - pracujący w firmie krócej niż rok } \\
\text { - telepracownicy } \\
\text { - zatrudnieni na podstawie umów cywilno- } \\
\text { prawnych } \\
\text { - pracujący w niepełnym wymiarze - umowa o pracę } \\
\text { - osoby z wykształceniem wyższym }\end{array}$ \\
\hline $\begin{array}{l}\text { Docenianie pracowników } \\
\text { i wyrażanie uznania przez } \\
\text { przełożonego }\end{array}$ & $\begin{array}{l}\text { - mężczyźni } \\
\text { - pracujący powyżej } 10 \text { lat }\end{array}$ \\
\hline Dodatkowa opieka zdrowotna & osoby w wieku 56 lat i więcej \\
\hline $\begin{array}{l}\text { Karnety sportowo-rekreacyjne } \\
\text { finansowane przez firmę }\end{array}$ & pracujący w pełnym wymiarze - umowa o pracę \\
\hline $\begin{array}{l}\text { Możliwość decydowania } \\
\text { o sposobie realizacji zadań }\end{array}$ & $\begin{array}{l}\text { - osoby w wieku do } 35 \text { lat } \\
\text { - specjaliści }\end{array}$ \\
\hline $\begin{array}{l}\text { Możliwość stałego rozwoju } \\
\text { kompetencji i łatwy dostęp } \\
\text { do programów rozwojowych }\end{array}$ & $\begin{array}{l}\text { - specjaliści } \\
\text { - pracujący 1-10 lat } \\
\text { - osoby w wieku do } 45 \text { lat }\end{array}$ \\
\hline $\begin{array}{l}\text { Możliwość zgłaszania } \\
\text { propozycji usprawnień }\end{array}$ & $\begin{array}{l}\text { - osoby z wykształceniem średnim } \\
\text { - pracownicy wykonawczy } \\
\text { - telepracownicy }\end{array}$ \\
\hline
\end{tabular}


cd. tabeli 2

\begin{tabular}{|c|c|}
\hline $\begin{array}{l}\text { Instrumenty budowania } \\
\text { zaangażowania }\end{array}$ & Najbardziej podatni odbiorcy \\
\hline $\begin{array}{l}\text { Nagradzanie najlepszych } \\
\text { pomysłów }\end{array}$ & $\begin{array}{l}\text { - pracownicy wykonawczy } \\
\text { - osoby z wykształceniem średnim } \\
\text { - pracujący powyżej } 4 \text { lat } \\
\text { - pracujący w pełnym wymiarze - umowa o pracę } \\
\text { - mężczyźni }\end{array}$ \\
\hline Premie i nagrody & $\begin{array}{l}\text { - osoby z wykształceniem podstawowym i zawodowym } \\
\text { - osoby z wykształceniem średnim }\end{array}$ \\
\hline $\begin{array}{l}\text { Ocenianie i wyrażanie przez } \\
\text { przełożonego uznania dla pracy }\end{array}$ & pracownicy wykonawczy \\
\hline $\begin{array}{l}\text { Równe traktowanie wszystkich } \\
\text { pracowników }\end{array}$ & $\begin{array}{l}\text { - kobiety } \\
\text { - pracujący w niepełnym wymiarze - umowa o pracę } \\
\text { - zatrudnieni na podstawie umów cywilno- } \\
\text { prawnych } \\
\text { - pracujący w firmie krócej niż rok } \\
\text { - osoby w wieku 46-55 lat }\end{array}$ \\
\hline $\begin{array}{l}\text { Stosowanie przejrzystych } \\
\text { kryteriów wynagradzania } \\
\text { i awansów }\end{array}$ & pracujący $1-3$ lat \\
\hline $\begin{array}{l}\text { Stworzenie warunków } \\
\text { do samorealizacji }\end{array}$ & menedżerowie \\
\hline $\begin{array}{l}\text { Świadczenia dodatkowe } \\
\text { (samochód, telefon, laptop) }\end{array}$ & $\begin{array}{l}\text { - osoby w wieku } 36-45 \text { lat } \\
\text { - osoby w wieku } 56 \text { lat i więcej } \\
\text { - osoby z wykształceniem podstawowym i zawodowym }\end{array}$ \\
\hline Udział w atrakcyjnym projekcie & osoby z wykształceniem wyższym \\
\hline Udział w szkoleniach & $\begin{array}{l}\text { - pracujący 1-3 lat } \\
\text { - osoby z wykształceniem wyższym }\end{array}$ \\
\hline Wspieranie pracy zespołowej & telepracownicy \\
\hline $\begin{array}{l}\text { Przejrzysta ścieżka kariera } \\
\text { zawodowej }\end{array}$ & osoby w wieku 36-45 lat \\
\hline Stabilność zatrudnienia & osoby w wieku 56 lat i więcej \\
\hline $\begin{array}{l}\text { Zdefiniowanie obowiązków } \\
\text { w taki sposób, by praca była } \\
\text { wyzwaniem }\end{array}$ & menedżerowie \\
\hline
\end{tabular}

Źródło: opracowanie własne na podstawie badań IPiSS.

Wyniki badań ankietowych przeprowadzonych przez IPiSS pozwoliły na stworzenie listy instrumentów motywowania i sposobów budowy zaangażowania i określenie najbardziej podatnych na nie pracowników (zob. tabela 2). Spojrzenie takie umożliwia ocenę zasadności stosowania niektórych rozwiązań motywacyjnych oraz podjęcie decyzji o rozwijaniu dziedzin, które charakteryzują się wysoką efektywnością. 
Analiza statystyczna uzyskanych wyników pozwoliła na ustalenie stopnia skuteczności czynników motywowania pogrupowanych w czterech blokach wobec różnych kategorii pracowników.

Czynniki związane z wynagrodzeniem najsilniej działają na osoby starsze, o dłuższym stażu w firmie, na mężczyzn, a ponadto na pracowników z wykształceniem średnim i podstawowym. Najsłabsze jest ich oddziaływanie na telepracowników, osoby zatrudnione krótko, młode, kobiety oraz na specjalistów i menedżerów.

Czynniki dotyczące satysfakcjonującego środowiska pracy szczególnie mocno oddziałują na pracowników w średnim wieku i o średnim stażu pracy w firmie, na mężczyzn oraz osoby z wykształceniem podstawowym, a także na pracowników zatrudnionych na stanowiskach wykonawczych. Zdecydowanie najmniej wrażliwe na te czynniki okazały się kobiety oraz specjaliści, a także pracownicy z najkrótszym i najdłuższym stażem.

Silną podatność na oddziaływanie instrumentów rozwojowych wykazują osoby o niskim poziomie wykształcenia (z wykształceniem podstawowym i średnim), pracownicy z krótkim stażem pracy (1-3 lat w firmie), mężczyźni oraz menedżerowie. Instrumenty rozwojowe słabo oddziałują na pracowników z wyższym wykształceniem, kobiety oraz na najkrócej i najdłużej zatrudnionych.

Najszersze pozytywne oddziaływanie odnotowano w przypadku czynnika związanego z relacjami interpersonalnymi. Mało podatni nań okazali się tylko najmłodsi i najkrócej pracujący oraz kobiety.

Poszukując odpowiedzi na pytanie o najefektywniejszy zestaw instrumentów motywowania uwzględniających różnorodność potrzeb i oczekiwań zespołu pracowniczego, analizy IPiSS poszerzono o czynniki wpływające na spadek zaangażowania pracowników.

\section{Czynniki ograniczające zaangażowanie pracowników}

Podobnie jak w przypadku instrumentów motywowania w badaniach wykazano istnienie różnic w zakresie oceny wagi czynników oddziałujących na spadek zaangażowania związanych z przynależnością respondentów do wybranych grup zatrudnionych.

Spośród 11 objętych analizą czynników potencjalnie wpływających na ograniczenie motywacji do pracy za najsilniej demotywujące badani uznali nieatrakcyjne wynagrodzenie $(82,1 \%)$, niedocenianie wysiłku pracowników przez przełożonych $(78,9 \%)$ oraz złą atmosferę w firmie (por. rys. 1). Warto podkreślić, że pracodawcy w trakcie przeprowadzanych wywiadów także uznali te czynniki za mające najbardziej negatywny wpływ na poziom zaangażowania. 


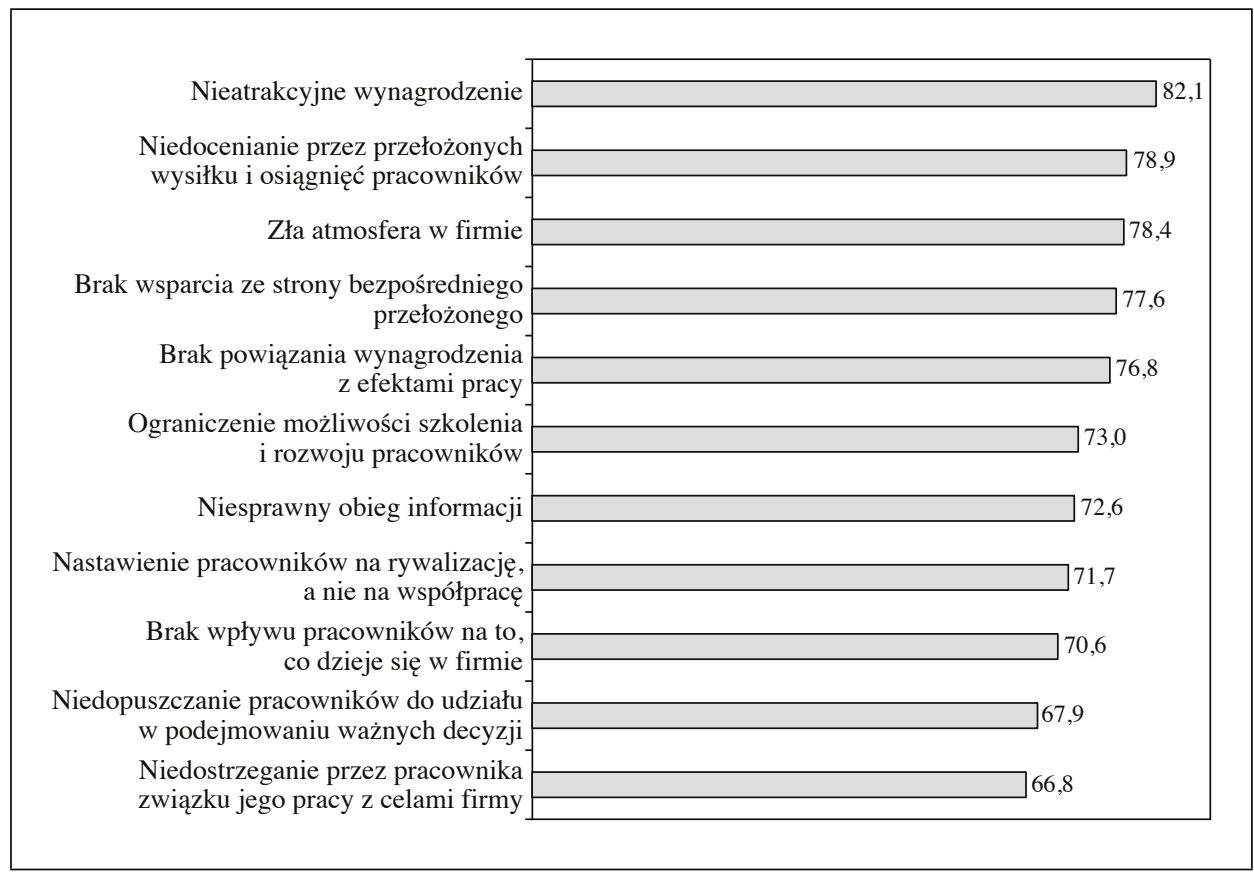

Rys. 1. Czynniki obniżające motywację do pracy w ocenie pracowników (\% wskazań) Źródło: opracowanie własne na podstawie [Kształtowanie zaangażowania... 2016, s. 139].

Analizy cząstkowe przeprowadzone z uwzględnieniem płci respondentów wykazały, że kobiety częściej dostrzegają znaczenie poszczególnych demotywatorów niż mężczyźni (por. tabela 3). Dla pracownic szczególnie dotkliwą praktyką jest niedocenianie ich wkładu pracy przez przełożonych oraz panująca $\mathrm{w}$ firmie zła atmosfera. Mężczyźni za mocno obniżające zaangażowanie w pracę uważają nieudzielanie zatrudnionym wsparcia przez przełożonych. Brak takiej pomocy wpływa szczególnie negatywnie na postawy pracowników młodych (poniżej 35 lat), którzy uznają ten czynnik za ważniejszy niż niskie wynagrodzenie.

Z kolei zdaniem bardziej doświadczonych pracowników, w wieku 46-55 lat, jedną z praktyk najsilniej obniżających motywację do pracy jest atmosfera rywalizacji panująca w firmie. Osoby te $\mathrm{z}$ racji posiadanych kompetencji i pozycji zawodowej osiągnęły już pewną stabilizację, dlatego zwykle nastawiają się na pracę zespołową, uznając konieczność udziału w „wyścigu szczurów” za rzecz uciążliwą i wyniszczającą. Dla najstarszych członków załogi (w wieku powyżej 56 lat) czynnikiem szczególnie demotywującym (obok wspomnianego nieatrakcyjnego wynagrodzenia i złej atmosfery w firmie) jest brak związku między wysokością wynagrodzenia a efektami pracy. 


\begin{tabular}{|c|c|c|c|c|c|c|c|c|}
\hline \multirow{3}{*}{ 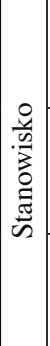 } & 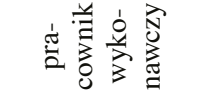 & $\begin{array}{l}\stackrel{ }{\infty} \\
\stackrel{1}{\curvearrowright}\end{array}$ & 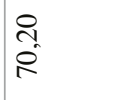 & $\begin{array}{l}\infty \\
\infty \\
\infty \\
\infty\end{array}$ & $\frac{o}{i}$ & $\begin{array}{l}8 \\
n \\
i \\
\infty \\
\infty\end{array}$ & $\frac{8}{\stackrel{2}{\curvearrowright}}$ & $\begin{array}{l}0 \\
\infty \\
\infty \\
\infty \\
\infty\end{array}$ \\
\hline & $\begin{array}{l}\frac{\dot{\sigma}}{0} \\
\frac{\pi}{n} \\
\frac{\pi}{n}\end{array}$ & $\frac{0}{2}$ & $\begin{array}{l}\stackrel{\rho}{2} \\
\stackrel{2}{2} \\
\stackrel{2}{2}\end{array}$ & in & $\begin{array}{l}\stackrel{2}{2} \\
\stackrel{2}{2} \\
\stackrel{2}{2}\end{array}$ & $\begin{array}{l}8 \\
i \\
i\end{array}$ & $\begin{array}{l}0 \\
2 \\
2\end{array}$ & 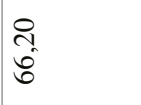 \\
\hline & 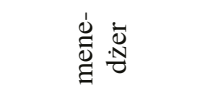 & $\begin{array}{l}\Re \\
\text { ホ̀ }\end{array}$ & $\begin{array}{l}\infty \\
\infty \\
i \\
i\end{array}$ & $\begin{array}{l}\infty \\
\infty \\
\infty\end{array}$ & 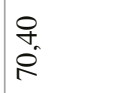 & 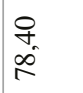 & \&. & $\begin{array}{l}\text { ஓ } \\
\text { ल }\end{array}$ \\
\hline \multirow{3}{*}{ 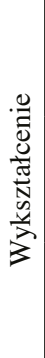 } & \begin{tabular}{l}
$\stackrel{8}{N}$ \\
$\stackrel{N}{N}$ \\
\multirow{3}{3}{}
\end{tabular} & $\stackrel{8}{+}$ & $\frac{0}{i}$ & $\begin{array}{l}\infty \\
\infty \\
i\end{array}$ & $\begin{array}{l}0 \\
n \\
i \\
\pi\end{array}$ & $\begin{array}{l}R \\
\infty \\
\infty\end{array}$ & $\begin{array}{l}\text { } \\
+ \\
i \\
\infty\end{array}$ & $\begin{array}{l}8 \\
8 \\
8\end{array}$ \\
\hline & 皃 & in & $\begin{array}{l}\infty \\
\infty \\
0 \\
0\end{array}$ & fo & $\frac{2}{i}$ & $\begin{array}{l}8 \\
2 \\
2 \\
2\end{array}$ & $\stackrel{R}{\stackrel{2}{i}}$ & 8 \\
\hline & 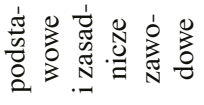 & $\begin{array}{l}\infty \\
\infty \\
0\end{array}$ & $i n$ & $\begin{array}{l}8 \\
\stackrel{8}{2}\end{array}$ & $\begin{array}{l}\text { § } \\
\text { tे }\end{array}$ & $\frac{0}{\infty}$ & $\underset{i}{\stackrel{q}{i}}$ & $\begin{array}{l}\text { స్ } \\
\text { ชิ }\end{array}$ \\
\hline \multirow{4}{*}{$\stackrel{\frac{\pi}{3}}{3}$} & 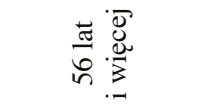 & 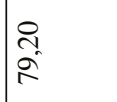 & $\begin{array}{l}0 \\
n \\
\infty \\
0\end{array}$ & $\begin{array}{l}8 \\
\infty \\
\infty \\
\infty\end{array}$ & $\begin{array}{l}\text { q } \\
\text { s. }\end{array}$ & $\frac{n}{\infty}$ & $\stackrel{2}{\stackrel{2}{*}}$ & $\begin{array}{l}0 \\
\text { ల్ } \\
\text { هి }\end{array}$ \\
\hline & in & $m$ & $\stackrel{0}{ }$ & \begin{tabular}{l}
$\infty$ \\
$\infty$ \\
\multirow{1}{*}{}
\end{tabular} & $\begin{array}{l}\stackrel{0}{0} \\
\text { r. }\end{array}$ & 品 & $\begin{array}{l}\text { in } \\
\text { in }\end{array}$ & $\begin{array}{l}\stackrel{2}{6} \\
20\end{array}$ \\
\hline & 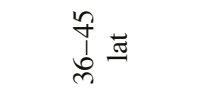 & ஓ & $\begin{array}{l}0 \\
\infty \\
\infty \\
\infty\end{array}$ & $\begin{array}{l}\text { } \\
\text { + } \\
\text { i }\end{array}$ & $\begin{array}{l}\stackrel{2}{\infty} \\
\infty\end{array}$ & $\infty$ & $\begin{array}{l}8 \\
\stackrel{8}{1}\end{array}$ & $\begin{array}{l}\text { î. } \\
\text { ஜn }\end{array}$ \\
\hline & $\begin{array}{l}\frac{z}{n} \\
n \\
0 \\
0\end{array}$ & $\begin{array}{l}8 \\
\mathbb{8} \\
i \\
\infty\end{array}$ & $\begin{array}{l}\text { in } \\
\text { in }\end{array}$ & 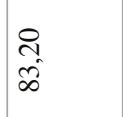 & $\begin{array}{l}8 \\
8 \\
2\end{array}$ & $\begin{array}{l}\infty \\
\infty \\
\infty\end{array}$ & $\begin{array}{l}0 \\
\frac{n}{\infty} \\
\infty\end{array}$ & $\begin{array}{l}0 \\
\text { r. } \\
i\end{array}$ \\
\hline \multirow{2}{*}{$\frac{0}{\tilde{N}}$} & 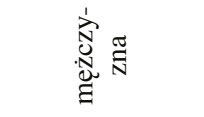 & $\begin{array}{l}\text { ळ. } \\
\text { ले }\end{array}$ & $\mathscr{b}$ & 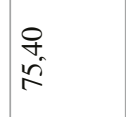 & $\begin{array}{l}n \\
n \\
6\end{array}$ & $\begin{array}{l}\stackrel{2}{2} \\
\stackrel{2}{2}\end{array}$ & $\stackrel{0}{2}$ & $\begin{array}{l}n \\
n \\
6 \\
6\end{array}$ \\
\hline & $\begin{array}{l}\frac{\pi}{0} \\
0 \\
0 \\
0\end{array}$ & $\frac{0}{2}$ & $\begin{array}{l}\text { g. } \\
\text { i }\end{array}$ & $\begin{array}{l}\stackrel{2}{2} \\
\text { શ் }\end{array}$ & 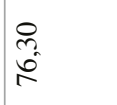 & \begin{tabular}{l}
$\stackrel{1}{1}$ \\
\multirow{\infty}{\infty}{}
\end{tabular} & $\stackrel{尺}{\infty}$ & $\begin{array}{l}\infty \\
\infty \\
80\end{array}$ \\
\hline & 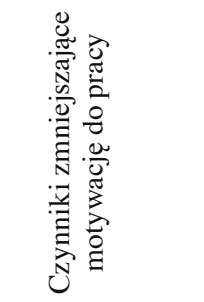 & 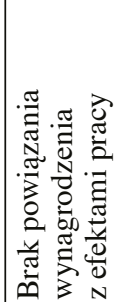 & 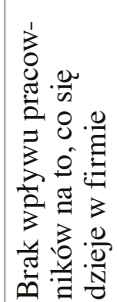 & 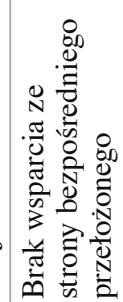 & 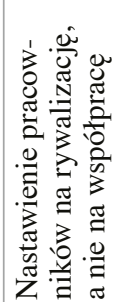 & 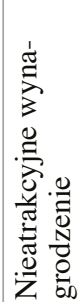 & 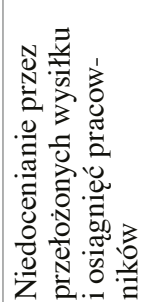 & 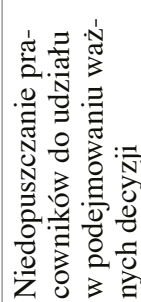 \\
\hline
\end{tabular}




\begin{tabular}{|c|c|c|c|c|c|}
\hline \multirow{3}{*}{ 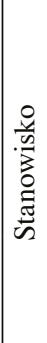 } & 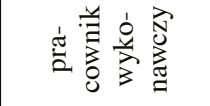 & $\begin{array}{l}\frac{0}{60} \\
8\end{array}$ & $\Re$ & n & ơ \\
\hline & $\begin{array}{l}\frac{1}{0} \\
\stackrel{\tilde{d}}{0}: \cong\end{array}$ & $\begin{array}{l}\text { Я. } \\
\text { ठे }\end{array}$ & $\begin{array}{l}i \\
i \\
i \\
i\end{array}$ & $\mathbb{N}$ & $\frac{8}{2}$ \\
\hline & 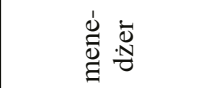 & $\begin{array}{l}\infty \\
\infty \\
0 \\
0\end{array}$ & p & $\begin{array}{l}\infty \\
\infty \\
1\end{array}$ & ơ \\
\hline \multirow{3}{*}{ 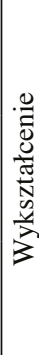 } & 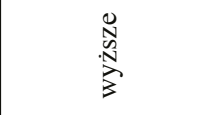 & $\begin{array}{l}8 \\
8 \\
\circ\end{array}$ & $\begin{array}{l}0 \\
\text { ల్. } \\
\text { م) }\end{array}$ & $\begin{array}{l}8 \\
8 \\
8\end{array}$ & $\begin{array}{l}\infty \\
\infty \\
\infty \\
\infty\end{array}$ \\
\hline & 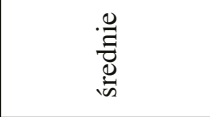 & 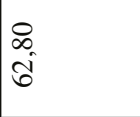 & $\begin{array}{l}R \\
\infty \\
0\end{array}$ & ڤे & $\begin{array}{l}n \\
n \\
n \\
n\end{array}$ \\
\hline & 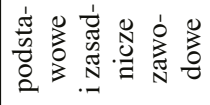 & $\begin{array}{l}\text { î } \\
\text { ó } \\
\text { f }\end{array}$ & $\frac{P_{n}}{n}$ & $\begin{array}{l}\text { ñ. } \\
\text { qे }\end{array}$ & $\begin{array}{l}\stackrel{R}{i} \\
\text { ín }\end{array}$ \\
\hline \multirow{4}{*}{$\frac{\breve{d}}{3}$} & 壳 & $\begin{array}{l}R \\
n \\
0\end{array}$ & $\stackrel{\text { Nે}}{\stackrel{ }{-}}$ & $\stackrel{8}{\stackrel{2}{*}}$ & 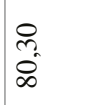 \\
\hline & $\begin{array}{l}n \\
i \\
b \\
+\end{array}$ & $\begin{array}{l}\infty \\
\infty \\
\text { î }\end{array}$ & $\stackrel{尺}{\stackrel{\overbrace{}}{6}}$ & $\begin{array}{l}R \\
\infty \\
0 \\
0\end{array}$ & in \\
\hline & 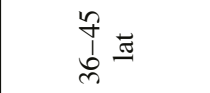 & $\underset{\substack{+6}}{T}$ & $\frac{1}{1}$ & $\frac{0}{m}$ & $\begin{array}{l}\infty \\
m \\
i\end{array}$ \\
\hline & $\begin{array}{l}\frac{\pi}{\pi} \\
\approx \\
0 \\
0\end{array}$ & $\begin{array}{l}\text { n. } \\
\text { ô. }\end{array}$ & $\begin{array}{l}\stackrel{1}{1} \\
\infty \\
\infty \\
\infty\end{array}$ & $\stackrel{8}{\circ}$ & $\frac{0}{\infty}$ \\
\hline \multirow{2}{*}{ 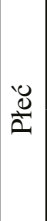 } & 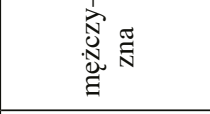 & $\tilde{6}$ & $\begin{array}{l}\AA \\
N \\
\infty \\
\infty\end{array}$ & $\stackrel{0}{i}$ & $\frac{0}{2}$ \\
\hline & $\frac{\pi}{0.0}$ & $\frac{R}{80}$ & $\begin{array}{l}\text { \& } \\
\text { ․ }\end{array}$ & $\begin{array}{l}8 \\
+1 \\
+1\end{array}$ & ஓे. \\
\hline & 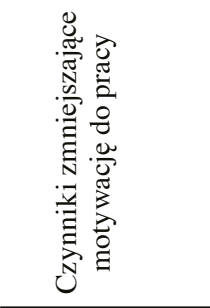 & 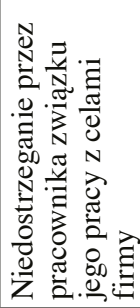 & 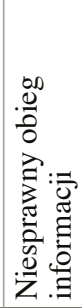 & 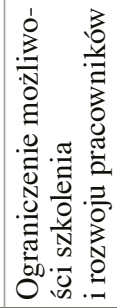 & 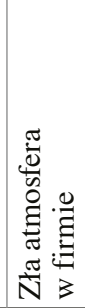 \\
\hline
\end{tabular}




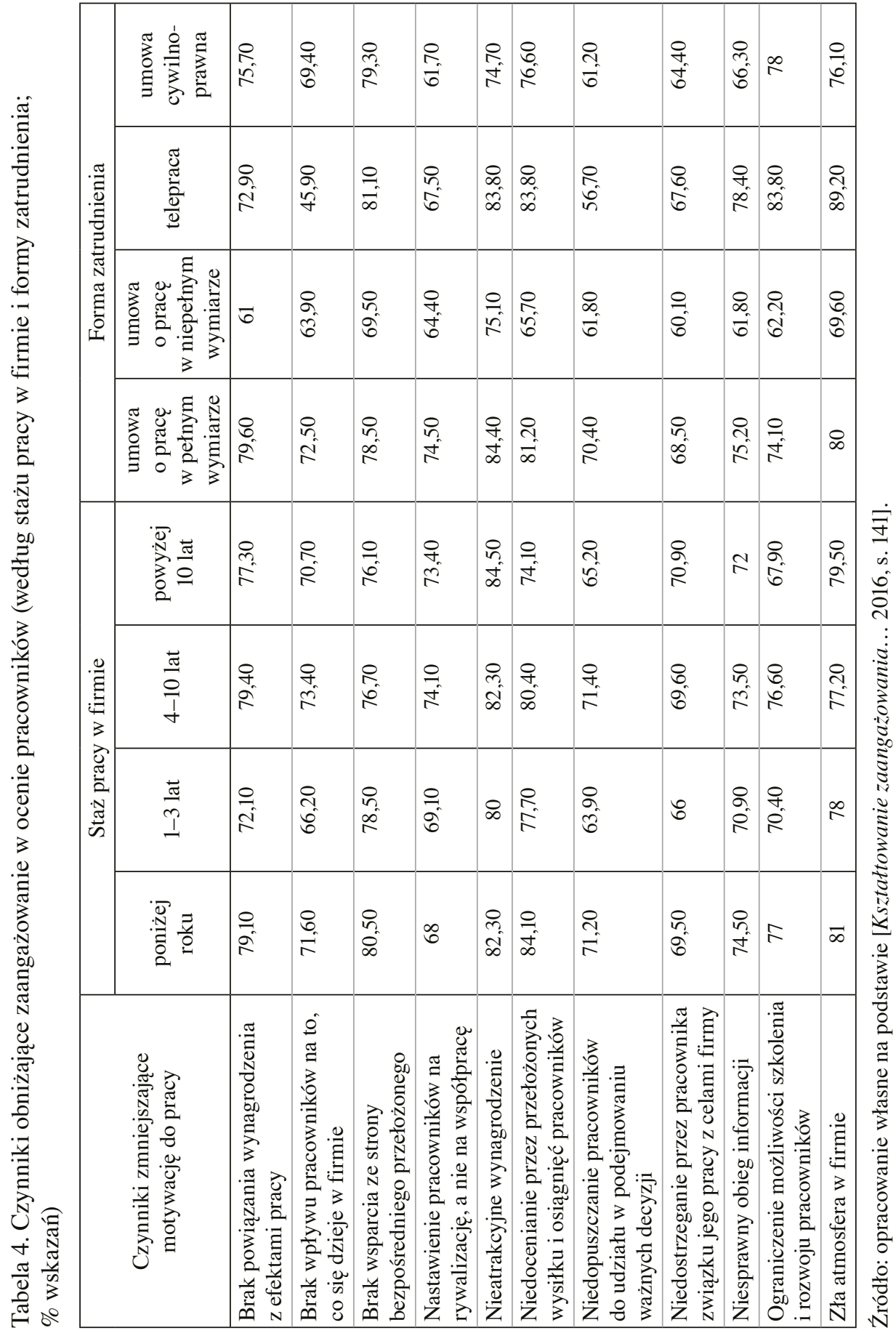


Pracownicy będący absolwentami szkół podstawowych, zawodowych i średnich do silnych demotywatorów zaliczyli m.in. niepewność wynikającą z braku wsparcia ze strony bezpośredniego przełożonego. Natomiast dla osób z wykształceniem wyższym, ceniących sobie odpowiedzialność za wykonywane zadania, czynnikami przyczyniającymi się do spadku zaangażowania są niedocenianie ich wysiłku przez przełożonych oraz brak powiązania wynagrodzenia z efektami pracy.

Analizy dotyczące stanowiska pracy wykazały, że zdaniem pracowników samodzielnych i dążących do stałego poszerzania swoich kompetencji, jakimi są menedżerowie, do dużego spadku zaangażowania mogą przyczynić się przede wszystkim utrudnienia w dostępie do szkoleń, brak możliwości rozwoju oraz niedostrzeganie ich wkładu pracy. Ten ostatni czynnik często wymieniali także specjaliści. Dla pracowników wykonawczych trudnym, silnie demotywującym doświadczeniem jest brak wsparcia ze strony bezpośredniego przełożonego.

Staż pracy w firmie także różnicuje oceny respondentów dotyczące czynników obniżających stopień zaangażowania (por. tabela 4). Dla osób dłużej związanych z organizacją (powyżej 4 lat) szczególnie niepokojącym zjawiskiem jest brak powiązania wynagrodzenia $z$ efektami pracy. Nowi pracownicy (ze stażem pracy krótszym niż rok) za demotywujące uznali niedocenianie ich wysiłku przez przełożonych. Z kolei według osób zatrudnionych w firmie 1-3 lat znacznym utrudnieniem jest brak wsparcia ze strony bezpośredniego przełożonego.

W zależności od formy zatrudnienia badani przypisywali różną wagę analizowanym czynnikom obniżającym motywację do pracy. Osobom pracującym w pełnym wymiarze godzin szczególnie uciążliwe wydaje się niedocenianie ich wysiłków przez przełożonego. Brak wsparcia ze strony przełożonego to silny demotywator w opinii pracowników zatrudnionych na tzw. etatach cząstkowych, zaś na zaangażowanie telepracowników oraz osób zatrudnionych na podstawie umów cywilnoprawnych negatywnie wpływa brak dostępu do programów rozwoju. Pracownicy zatrudnieni w elastycznych formach ten ostatni czynnik uznawali za dotkliwy znacznie częśsiej niż osoby wykonujące swoje zadania w ramach umów o pracę. Interesujące były wyniki badań dotyczące zatrudnionych na podstawie umów cywilnoprawnych. Wyróżniało ich mniejsze przywiązywanie wagi do wysokości wynagrodzenia oraz relacji panujących w firmie. Być może ze względu na zadaniowy charakter ich pracy oraz to, że nierzadko realizują ją poza siedzibą firmy, niskie wynagrodzenie i zła atmosfera w firmie (tj. demotywatory najczęściej wskazywane wśród trzech najistotniejszych przez pozostałe grupy pracowników) znalazły się na dalszych pozycjach. Pracownicy wykonujący prace zlecone i opracowujący dzieła autorskie za najmocniej obniżające ich zaangażowanie uznali natomiast brak wsparcia ze strony przełożonego oraz niedocenianie wysiłku wkładanego w pracę. 


\section{Podsumowanie}

Oparcie przewagi konkurencyjnej firmy na stworzeniu unikalnego, zaangażowanego (a więc także efektywnego i innowacyjnego) zespołu pracowników wymaga wcześniejszego dokonania wnikliwej analizy nie tylko sytuacji i potrzeb przedsiębiorstwa, ale także oczekiwań tworzących je ludzi. Zaprezentowane wyniki badań wskazują na znaczenie różnicowania stosowanych przez firmy instrumentów motywowania. Dostarczają one dowodów na niejednorodność potrzeb, preferencji i poglądów formułowanych w tym zakresie przez kobiety i mężczyzn, osoby w różnym wieku, o różnym poziomie wykształcenia i stażu pracy, na różnych stanowiskach oraz reprezentujących różne formy zatrudnienia. Jednocześnie przeprowadzone analizy potwierdziły istnienie podobieństw w ocenach metod i narzędzi budowania zaangażowania oraz czynników je obniżających formułowanych przez pracowników o wspólnych cechach społeczno-demograficznych. Udowodniono występowanie istotnych statystycznie związków między preferowanymi instrumentami motywowania a przynależnością osób zatrudnionych do określonej grupy. Jedyną zmienną, w której przypadku nie odnotowano korelacji, był typ stanowiska pracy.

Niestety badania IPiSS zdają się wskazywać na niedocenianie przez pracodawców wagi różnicowania instrumentów budowania zaangażowania pracowników. Świadczy o tym nie tylko małe zainteresowanie firm zarządzaniem różnorodnością, ale także opinie badanych o uwzględnianiu w procesach zarządczych ich potrzeb. Tylko niespełna połowa osób zatrudnionych jest bowiem zdania, że kierownictwo ich organizacji bierze pod uwagę oczekiwania pracowników wobec firmy.

Nieuwzględnianie opinii pracowników i traktowanie wszystkich zatrudnionych jako jednorodnej grupy może obniżać skuteczność zarządzania zasobami ludzkimi oraz utrudniać uwolnienie pełni potencjału drzemiącego w różnorodności zespołu. W skrajnych przypadkach podejście takie może doprowadzić do utraty najcenniejszych zasobów kompetencyjnych firmy, gdy niedoceniani i ignorowani pracownicy postanowią rozstać się z organizacją. W czasie narastającej rywalizacji przedsiębiorstw o talenty, młodych pracowników oraz specjalistów tworzenie systemów motywowania uwzględniających różnice istniejące między ludźmi wydaje się warunkiem przetrwania. Pozostaje wierzyć, że z czasem liczba funkcjonujących w Polsce firm dostrzegających tę konieczność będzie rosła, a zarządzanie różnorodnością na trwałe wpisze się w rodzimy pejzaż gospodarczy. 


\section{Literatura}

Borkowska S. [2006], Motywacja i motywowanie [w:] Zarzqdzanie zasobami ludzkimi. Tworzenie kapitału ludzkiego organizacji, red. H. Król, A. Ludwiczyński, PWN, Warszawa.

Bridger E. [2015], Employee Engagement, Kogan Page, London.

The Business Case for Diversity. Good Practices in the Workplace [2005], European Commission.

Colan L.J. [2009], Engaging the Hearts and Minds of All Your Employees, McGraw-Hill, New York.

Cook S. [2008], The Essential Guide to Employee Engagement. Better Business Performance through Staff Satisfaction, Kogan Page, London.

Croston D. [2008], Employee Engagement. The People First. Approach to Building a Business, Moonstone Media, Sydney.

Federman B. [2009], Employee Engagement. A Roadmap for Creating Profits, Optimizing Performance, and Increasing Loyalty, Jossey-Bass, San Francisco.

Gryszko M. [2009], Zarzq̨dzanie różnorodnościq w Polsce, Raport Forum Odpowiedzialnego Biznesu, www.odpowiedzialnybiznes.pl.

Guthie J.P. [2001], High-Involvement Work Practices, Turnover, and Productivity: Evidence from New Zealand, „Academy of Management Journal”, vol. 44, nr 1, https:// doi.org/10.2307/3069345.

Halm B. [2011], Employee Engagement: A Prescription for Organizational Transformation [w:] Organization Development in Healthcare: Conversations on Research and Strategies, eds J.A. Wolf et al., „Advances in Health Care Management”, vol. 10.

Juchnowicz M. [2012], Zaangażowanie pracowników. Sposoby oceny i motywowania, PWE, Warszawa.

Kaye B., Jordan-Evans S. [2012], Zatrzymaj najlepszych. 26 strategii budowania zaangażowania pracowników, Wolters Kluwer, Warszawa.

Kirton G., Greene A. [2005], The Dynamics of Managing Diversity, Elsevier, Oxford.

Kochan T.A., Dyer L. [1993], Managing Transformational Change: The Role of Human Resources Professionals, „International Journal of Human Resource Management”, nr 4(3).

Kocór M., Strzebińska A. [2010], Jakich pracowników potrzebuja polscy pracodawcy?, PARP, Warszawa.

Konrad A.M. [2006], Engaging Employees through High-involvement Work Practices, „Ivey Business Journal”, nr 3-4, March/April.

Kształtowanie zaangażowania pracowników w kontekście zarzqdzania różnorodnościq [2016], red. S. Borkowska, A. Jawor-Joniewicz, IPiSS, Warszawa.

Lawler E.E. III, Mohrman S.A., Benson G.S. [2001], Organizing for High Per-formance: The CEO Report on Employee Involvement, TQM, Reengineering, and Knowledge Management in Fortune 1000 Companies, Jossey-Bass, San Francisco.

Lisowska E., Sznajder A. [2013], Zarzq̨dzanie różnorodnościq w miejscu pracy. Raport z I edycji Barometru Różnorodności, Konfederacja Lewiatan, Warszawa.

Lisowska E., Sznajder A. [2014], Zarzq̨dzanie różnorodnościq w miejscu pracy. Raport z II edycji Barometru Różnorodności, Konfederacja Lewiatan, Warszawa. 
Rashid M.Z.A., Sambasivan M., Johari J. [2003], The Influence of Corporate Culture and Organisational Commitment on Performance, ,Journal of Management Development", vol. 22, nr 8, https://doi.org/10.1108/02621710310487873.

Rodgers J.O., Hunter M. [2003], Diversity Management Isn't about Managing for a Group Identity. It's about Managing for the Individual, „Handbook of Business Strategy”, vol. 4, nr 1.

Rola ZZL w kreowaniu innowacyjności organizacji [2010], red. S. Borkowska, Wydawnictwo C.H. Beck, Warszawa.

Smith J. [2006], Empowerment. Jak zwiększać zaangażowanie pracowników, Helion, Gliwice.

UKCES Employer Skills Survey [2015], https://www.europeandataportal.eu/data/en/dataset/ukces-employer-skills-survey-2015.

Worek B., Stec K., Szklarczyk D., Keler K. [2011], Kto nas kształci po ukończeniu szkoły?, PARP, Warszawa.

Wziątek-Staśko A. [2012], Diversity Management. Narzędzie skutecznego motywowania pracowników, Difin, Warszawa.

\section{Motivating Diversified Employee Groups}

(Abstract)

Research shows that worker engagement influences their level of innovation and performance. In forming engagement, which employers so highly desire, and which can be accomplished with the use of effective instruments of motivation, an individual approach seems the most efficacious, as it allows for a fuller satisfaction of employee needs. The aim of this article is to analyse methods and tools for motivating different groups of employees, taking into account persons of different age, sex, education, function, work experience at the company and employed under different forms of employment. An attempt is made to determine if people who are similar in terms of the features listed above prefer similar instruments of motivation. The results of qualitative and quantitative research conducted by the Institute of Labor and Social Studies in Warsaw in 104 SME's are used in an effort to make that determination.

Keywords: diversity management, human resource management, engagement, motivational systems. 